\title{
The borderless designs in the age of digital technology: The shifting and reinvention of kebaya designs in Indonesia
}

\author{
Tan Paulina Candra Agista \\ Culture and Media Studies, Graduate School, Universitas Gadjah Mada, Jl. Teknika Utara, \\ Yogyakarta, Indonesia, 55284 \\ e-mail: paulina.candratan@gmail.com
}

\begin{abstract}
People, products, technology, and information have influenced each other since life began. History has shown that the work of art as a manmade product in the society receives influence from many different angles such as power and technology. That influence has grown bigger and wider as globalization expands. The development in the world of technology and information gives a different yet significant impact to people's lives. What has happened in the increased global world leads to the formation of borderless society. The intertwined cultural identities became the root of the revolutionary changing in the reinvention of kebaya designs. The reproduction of kebaya designs shows that the designs have shifted from the main stream designs to the borderless designs. The old patterns of kebaya are modified by combining materials and new patterns that have never been appeared in the main stream kebaya designs. Based on the above explanation, this paper explores the reinvention of kebaya by Anne Avantie (Indonesian remarkable designer) and the rapid distribution of the copies in this digital technology era. The result of this study shows that the borderless kebaya designs are well accepted by the society.
\end{abstract}

\section{Keywords}

Avantie's kebaya, borderless society, digital technology era, globalization, kebaya design

\section{Introduction}

Citation: Agista, T.P. C. (2018). The borderless designs in the age of digital technology: The shifting and reinvention of kebaya designs in Indonesia. In M. Amini, M. Yusuf, \& V. I. Yulianto. (Eds.), UGM Digital Press Social Sciences and Humanities: Vol. 1. Proceeding of the 2nd International Conference on South East Asia Studies, (pp. 127-133).

Published: October, 2018
The fall of New Order Government that changed the political situation in Indonesia was a turning point for a more open situation in Indonesia. This changing and globalization have been growing simultaneously. The reformation in 1998 enabled a wider access to information and technology. Therefore, the influence did not only touch the political factor yet it also influenced the economic and social factors.

Fashion designs which are always close to people's lives received the influence too. The Break-through in kebaya designs happened when Anne Avantie, the remarkable Indonesian kebaya designer, introduced her breaking rules kebaya. Her designs have deviated from the ordinary rules of kebaya design. However, what she has done, could be said as a way to save kebaya from its declining situation which may turn kebaya 
into a residual fashion. Without any break-trough, kebaya may lose its popularity. If it happens, the more popular fashion trend (most likely) is the western one will get some advantage from it. It will take over the position of kebaya.

On her way to achieve her success, Avantie faced some challenge. Her kebaya designs have been controversial. A group of main stream people who claimed themselves as the Indonesian culture lovers protested what she has done in reinventing the design of kebaya. They said that Avantie broke the pattern of kebaya making. Avantie (2012, p. 66) notes that she is considered as an irresponsible designer because she does not respect her ancestors and Kartini (an Indonesian heroin) cries when she sees Avantie's kebaya designs. On the other hand, Indonesian artists such as Agnes Monica, Dian Nintami, Atiqah Hasiholan, other artists and other women wear Avantie's kebaya happily. Based on that controversial situation, this paper is interested in using Avantie's biography Inspiration, Work \& Love as the object material of the study. Avantie's experience in the contestation of kebaya leads the researcher to do this study. This paper would answer three research questions (1) how does Avantie break the main stream kebaya? (2) How does the postcolonial power appear in her designs? (3) how does the polital power play the role in kebaya design? In order to find out the answers to the previously stated questions, this study uses genealogy to trace the factors that influence the changing of kebaya designs, the roles of kebaya in Indonesia and the political power that affects the development of kebaya. It is hoped that genealogy will give critical insights to this study and will provide critical analysis to answer the questions of this study.

\section{Findings}

\subsection{The History of Kebaya in Indonesia}

Kebaya as a national costume of Indonesian women has a long history. Sulastri divides the history of kebaya into five periods (Avantie, 2012: pp. 72-73). It is believed that before the 18 century kebaya had been introduced. The appearance of kebaya can be traced from the history of the word kebaya itself. Kebaya may come from the word habaya. Habaya is the Melayu female costume. At that time Indonesian women had not worn kebaya, they wore kemben (a piece of cloth without sleeves to close the women's chests) instead.

The emergence of habaya in Indonesia started when Moslem people came into Indonesia. In Indonesia the word habaya was then pronounced and known as kebaya. Kebaya was adapted to close kemben. The reason of putting on kebaya was to practice the Islamic teaching which saying that women must close the aurat (part of body required by Islam to be covered).

The second periods is between the 18 to the 19 century. At that time people from China came and lived in Indonesia. The arrival of the Chinese groups had brought with them their tradition in costume. The Chinese women introduced a type of kebaya which is called kebaya encim. Kebaya encim spread in Indonesia and it influenced the Indonesian women's way of putting on clothes. Therefore this design was adapted by Indonesian women. During that century, the female Dutch who were living in Indonesia were interested in wearing kebaya too. They introduced kebaya Noni. The use of lace began in this design. Kebaya Noni introduced western materials in the desings.

Unfortunately, the Dutch kebaya did not get a room to develop as kebaya was related to lower class Indonesian women. Dutch women who wore kebaya would be considered belong to this lower class women. Therefore the Dutch women ignored kebaya. They did not pay attention to the development of kebaya designs. As a result, the trend of this kebaya decreased and it lost its polularity. It is obvious that the political power of the Dutch government who colonized played a significant role in the development of this design. Since the colonial government secured its power by treating kebaya as lower class fashion, kebaya did not have the chance to develop. the Dutch women who put themselves in a higher position than that of Indonesian women were reluctant to wear kebaya. This practice shows that kebaya was used as a tool to create classes, to differentiate Western from Oreiental, free people and colonized people.

On the other hand, kebaya encim continued to exist. The Chinese women wore kebaya and this design invited Indonesian women to accept it. There was no refusal to this design. The Chinese women who wore kebaya were not considered as lower class citizens.

What happened to kebaya noni and kebaya encim proved that political power has an important role in the trend of certain fashion. Fashion can be used as a political tool to secure power or to create ceratin political situation that will benefit the power.

The next period is the era of kebaya Kartini. This design is the heritage of Kartini (Indonesian emancipation heroine). The emergence of kebaya Kartini is considered as the seed of Indonesian main 
stream kebaya. This design is similar to the design of kebaya encim. Both of them use the same materials. The part which is different is the length of kebaya. The length of kebaya Kartini is sligntly shorten than that of kebaya encim. This design adapts the chinese design. Kartini as the daughter of the Rembang Regency's Mayor, had big influence in the development of this design. The kebaya design that she wore was followed by common people. In fact, it can be said that Kartini was a kebaya trendsetter in her time. The popularity of kebaya Kartini became the reason for the Indonesia to choose this design as the root of the Indonesain main-stream kebaya.

The next trend is the kebaya from different regions in Indonesia. In the middle of 20th century to the 1980's, Indonesia knew what was called Kebaya Betawi, Sunda, Padang, Yogyakarta, Surakarta, Jawa Timuran, and Bali. The design from the different regions used tradisional accessories from each area. Kebaya was combined with tradisional material such as batik. At the end of 20th century kebaya was developing broadly.

The era of kebaya Avantie strarted in the 21 century or in the third milenium. She did breaking the rules of kebaya by designing the borderless line kebaya. She combines the traditional kebaya with the western fashion design. She addes western accessories to her design. She innovates a new trend of kebaya. She expresses her idea totally in presenting a new look kebaya. Although what she does is controversial, she cannot be stopped. Some people refuse her design, yet many other adore it and love it. The political situation in 1998 also sopported her to gain succes in kebaya designs. Reformation provided her with more freedom to develop kebaya designs.

The 1998 reformation that happened in Indonesia became the door for the development of kebaya. Triyanto states that the reformation era is a wide gate for designers (2011: 2). They started expressing their ideas bravely. Their designs were performed in the fashion shows, printed media or electronic media. What had been exposed widely attracted fashion lovers. This situation supported Avantie as a kebaya designer. She came up with a new design which was different from the main-stream kebaya.

The period between 20 century to 1980's was the time for contemporary ethnic kebaya that encouraged people to explore more kebaya designs. People began to search for new designs instead of the monotonous one. Avantie in replying to the demand, introduced a totally new kebaya design which violating from the main stream one. She came up with extraodinary ideas to change the appearance of kebaya.

Groups of the mainstream who are not delighted with Avantie's designs tried to put back kebaya in the old designs. They wanted kebaya stay with its main-stream rules. Uno mentions the characteristic of the main stream kebaya as follows (2014, p. 28):

1. It has opening in the front part (chest part). This style is popular as short and long kebaya.

2. It has opening in the back part. This syle is called baju kurung.

3. Kebaya which has front opening can have an additional ornament called bef (kutubaru).

4. It uses bottons or pins to fasten kebaya or they may be used as accessories.

5. The length of kebaya varies. Some cover the hips or covers the knees. Sometimes, it is as long as the length of the sleeves.

\subsection{The Reproduction of Kebaya}

Benjamin wrotes that in principle a work of art has always been reproducible (Durham and Kellner, 2006, pp. 18 -40). Man-made artifacts could always be imitated by men. This theory is in line with what Avantie has done in reproduction of kebaya. She uses western materials in her design and modifies the pattern of kebaya. Avantie does a break-trough in kebaya design by presenting a hybrid kebaya. She combines Indonesian kebaya material with colonial materials such as lace, embroideries, beads, golden and silver color. She modifies kebaya patterns by having different patterns of sleeves such as asymmetrical sleeves or baloon like sleeves, she decorates sleeves of kebaya with artificial flowers or big ribbons. She designs kebaya with a long tail (she imitates a western wedding gown). She designs kebaya with a Chinese collar (cheongsam collar), a backless kebaya, a fitted body kebaya. She designs kebaya with a low chest pattern. She combines kebaya with a long skirt. 
Table 1. Comparison between Main-stream kebaya and Avantie's Hybrid Kebaya

\begin{tabular}{|l|l|l|}
\hline & Main- stream Kebaya & Avantie's Hybrid Kebaya \\
\hline Pattern of Body & Loose & Fitted body \\
\hline Pattern of Sleeves & Symmetrical & symmetrical, \\
\hline Pattern of Collar & Kartini's Style & $\begin{array}{l}\text { Various styles: Kartini's style, } \\
\text { cheongsam, no collar }\end{array}$ \\
\hline Pattern of Back & Closed & Closed, backless \\
\hline Length of Kebaya & Above knees & Various length \\
\hline Material & Cotton & $\begin{array}{l}\text { Various materials: cotton, } \\
\text { brocade, chiffon, velvet }\end{array}$ \\
\hline Color & Main colors & $\begin{array}{l}\text { Various colors including } \\
\text { golden and silver colors. }\end{array}$ \\
\hline
\end{tabular}

Avantie's kebaya attracts more people to wear kebaya. Avantie stated that she participated in designing kebaya for the artis in the opening ceremony of 26th SEA GAMES INDONESIA 2011 (2012, p. 32). Agnes Monica, a famous Indonesian singer, put on Avantie's kebaya in her video clip. Avantie's idea in breaking the rules of main-stream kebaya has pulled kebaya to the fashion stage. What she has done is a way to save kebaya from its declining popularity. Triyanto (2011, p. 18) wrotes that kebaya attracts girls and women to wear kebaya as kebaya can be used as a media to perform fashionably.

\subsection{Globalization and the Distribution of Kebaya}

Globalization cannot be separated from people's lives. It influences the fashion business too and it surely touches kebaya designs. Screberny notes that globalization as the intensification of worldwide social relations which link distant localities in such a way that local happenings are shaped by events occurring many miles away and vice versa (Durham and Kellner, 2006, pp. 604-625). Screberny's statement explains that it is very possible Avantie's kebaya is influenced by fashion trend from other countries and what she does influences fashion business in other countries. These rapid and simultaneous inter connections are supported by the digital technology. Such a breakthrough is only possible when power supports. In a country where power closes access to outside world and limits the digital media development, the reinvention of designs is difficult to happen. Fashion designers who face such situation and condition will not have chance to innovate new designs. Fashion does not show any progress or development. The fashion industry stays or even declines.

The digital technology contributes to the distribution of Avantie's kebaya. The digital technology distributes the design to the faraway places and remote areas. Facebook, Youtube, Line, and Instagram contribute to the popularity of Avantie's kebaya. The digital technology turns the long distance into the short one. To see Avantie's designs people do not need to come to her workshop or to the fashion show, they can see them by accessing the social media. The products of the digital technology (facebook, instagram, line, youtube, etc.) change the way people enjoy Avantie's designs.

On the other hand, the digital technology makes the copies of Avantie's designs possible. Copies are made by lower class tailors to the high class designers. Avantie (2012, p. 80) wrotes that there are many people who get job by making kebaya "Ke Anne-Annean" (copies of Avantie's kebaya). This practice provides an opportunity to other designers to have better business by copying her designs. She even realizes that the practice of making copy of her designs cannot be stopped. Copying her desings becomes a common practice. No one considers it as an illegal copy. Every one is free to make copies. Avantie herself does not mind it. She tolerates this practice. The practice of copying by middle and lower class tailors enable more people to wear kebaya. When the number of people who wear kebaya increases, it means the popularity of kebaya increases too.

Furthermore, the digital technology provides positive impact to Avantie's fame. It enables people to have access to her designs, as a result her designs are widely known and they influence the kebaya trend. The digital technology also accelerates the distribution of her designs. The widely spread designs have affected the society. Avantie's designs are attractive as they look fashionable by using colonial designs and materials. Technology put itself as a significant contributor to Avantie's popularity. This success shows that society has crossed from main-stream side to the hybrid one. The new look kebaya attracts not only women but also young girls to wear kebaya. Kebaya is worn in different occasions such as independent day, wedding party, graduation day and other national days. Kebaya business is getting better. Kebaya is displayed in boutiques in shopping malls. 
From the technology point of view, the distribution or the reproduction kebaya by Avantie is supported by the digital technology. Reproduction has passed several stages. In the old times, the reproduction was the manual one. After that it was the mechanical reproduction age and nowadays it is the digital reproduction era.

Each reproduction time has its own characteristics. In the time of manual reproduction, only the original product is accepted. Other than that is considered false product. Copying is not a common practice. The manual reproduction consideres the quality of the work is lower than that of the original one.

In the time of mechanical reproduction, the idea of originality changed since the mechanical reproduction accepts copies of the work. Copying becomes common. The mechanical reproduction enables people to copy some work massively. This practice is used in order to fulfill the needs of users.

In the digital era, the reproduction of the work of art is very difficult to be controlled. Davis (1995: 381) in the article The Work of Art in the Age of Digital Reproduction, stated that the work of art in the digital era is like a chameleon. There is no fundamental difference between the original work and its copy.

The digital reproduction of Avantie's kebaya bring three consequences. First, the distribution of the designs happens very quickly and widely. Second, people can make the copies in an unlimited quantity. Third, there is manipulation towards Avantie's kebaya design. What happens to Avantie's designs affirms Lessig's statement (2004, p. 3) about manipulation in the work of art in the digital era; to crack, to mix, and to burn. To crack in kebaya design means to take and to use the parts of kebaya which have been used, to mix means to mix those parts and to burn means to copy the design in unlimited copies.

\subsection{Avantie's Kebaya in Post Reformation Society}

The reproduction of main stream kebaya does not only change the design, but it also changes the position of kebaya in the society. In the new order government, kebaya was used as a political machine to create social class (middle class to upper class) for women who belongs to government officers' family or those who becomes government officer's wives.

Yuastuti and Pamungkas (2016, p. 564) in her article, Gaya Busana Siti Hartinah Soeharto Sebagai Ibu Negara Indonesia Tahun 1968-1996 wrotes that, in the new order era, kebaya was dominated by new order political power as symbols for the middle class to upper class officers' family. Kebaya was used as the uniforms in many organizations such as Dharma Wanita, PKK, Persit Candra Kirana (for wives of Indonesian Army), Jalasenastri (for wives of Indonesian Air Force), and PIA Ardhya Garini (for wives of Indonesian Navy), and Bhayangkari (for wives of Indonesian Policemen).

At that time, kebaya uniform was used to distinguish groups of women who participated in the government organizations from those who did not take part in those organizations. Kebaya was considered as a symbol of good manner that belongs to obidient women. Kebaya was used as a tool to create a mootherhood concept as the concept of Javanese women. Kebaya was used as propaganda.

During that period, it seemed kebaya did not give a room to women to move. Kebaya was the tool to reproduce the concept of women as the second class citizens. However, the practice of using kebaya as a political machine weakened since the era of reformation began in Indonesia.

Democracy gave a wider chance for women to take part in any field including political activities. Women had more opportunity to perform and to express their ideas.

Reformation opened a door for the entrance of western culture, especially American culture. It is assumed that Indonesia has been influenced intensively by American culture. Budianta in her article Discourse of Cultural Identity during the 1997-1998 Monetary Crisis (2010, p. 113) wrotes:

\footnotetext{
"the presence of America in Indonesia is not only the evident in popular culture industries (music, film, television serials), but also in franchising of retail centers (Tops, Sears, Seven-Eleven, Disney's Shop, Wool-worth's) and fast food industries (McDonalds, Kentucky Fried Chicken, Pizza Hut, Sizzler, T.G.I. Fridays). The popularity of things American, especially among the young generation, has been on the rise, and parallels the acceleration of customer culture in the last decade."
}

The strong flow of American culture which came to Indonesia was surely influenced the fashion trend in Indonesia and the way Indonesian women thought. Music, films, television series also contributes to the change in Indonesia. By listening to American music and watching American movies and films, Indonesians could not protect themselves from the influence of American culture. The freedom in expressing ideas and creativity that appeared in those films and movies motivated and encouraged Indonesian women to do the same practice. The door to the western culture was opened widely. As a result, the chance to express creativity through the work of art received the wider chances too. Heryanto $(1998$, p. 126) noted that the access to western influnce is tolarable. Western culture was accepted by Indonesians. Therefore the 
western fashion design influenced Indonesian fashion design too. This situation affected the design of kebaya too. Modification of kebaya began. Western patterns and materials were applied into kebaya design.

\subsection{Reformation turned the main stream kebaya into the hybrid one}

In fashion design, especially kebaya, Indonesian women found out that the reproduction of kebaya design by Avantie becomes the symbol for welcoming freedom. The reinvention of the design that presents modern, cosmopolitan, and fashionable designs is accepted by Indonesian women since they have been waiting for better chance to experience some progress and to develop themselves in this era. Avantie's kebaya design answers the need of Indonesian women.

The acceptance of this hybrid designs shows that Indonesain women do not use culture proximity between western culture and Indonesian culture to accept the design. The reason is that the hybrid kebaya designs can fulfill the need of being modern and fashionable. Moreover, the hybrid kebaya design provides flexibility for Indonesian women when wearing kebaya as they can combine kebaya with trousers or skirts. Freedom becomes a part of this design and it supports the idea that Indonesian women are not subordinate and they are equal to men. The pendulum swang from the unity to diversity, from mainstream to hybridity.

\section{Discussions}

The fundamental findings of this study show that Avantie breaks the main-stream kebaya by modifying the pattern and using different kinds of materials and colors that never been used in the main-stream kebaya. She introduced kebaya with total creativity. She used the moment of reformation optimally to create new designs. She could present new look kebaya designs that attract more Indonesian women to love kebaya and to wear kebaya proudly. By doing this, Avantie has saved kebaya from the declining trend which may take kebaya into the residual condition.

She introduces western fashion design in her kebaya designs. Patterns of sleeves, body, back, chest, length of kebaya are dominated by western style. The colonial's influence appears a lot in Avantie's kebaya. It dominates the performance of her designs. However, she is a trend-setter in kebaya designs. Lower class to upper class tailors copy her kebaya designs. She has many followers and even fandom in cities in Indonesia. This affirms that the position of creativity is very important in kebaya design and its position is higher than nationality. If creativity in kebaya design is prisoned and there is not any innovation, kebaya trend may aweakens. As a result, the more powerful western fashion trend may occupy Indonesian fashion world.

The third answer to the question of this study shows that in the time of the new order kebaya was used as a political tool to control women. However, the 1998 reformation changed the situation. The reformation also touched the kebaya fashion world. Indonesian women gained the freedom by accepting and wearing Avantie's kebaya. Since that time kebaya designs have developed broadly. The better economic condition in Indonesia enables people to enjoy more expensive fashion designs. This condition supports kebaya designers, such as Avantie to innovate more in designing kebaya.

\section{Conclusions}

Having discussed the concept of reproduction and globalization, this study concludes that the hybrid design affirms the colonial domination although Indonesia is not colonized. Upstone (2008, p. 6) notes that colonial spatial order is a conscious act, a purchase of an imagery, on the part of the colonizer in order to secure power. However, this practice puts Avantie as a trendsetter in kebaya design. Furthermore, Avantie's achievement in kebaya business affirms that in the kebaya design, identity is fluid. Acceptance of the western culture in kebaya designs proves that there is no strict border in this business. Walton (2008, p. 101) stated that identity is not something fixed. Identity is fluid and it can change. What Walton mentions has been confirmed by Avantie's success in hybrid kebaya designs. The digital technology contributes to the success of Avantie. Technology makes possible the distribution of this design widely and rapidly. It accelerates the influence of hybridity to the society and it gives wide access to people to make copies. The 1998 reformation in Indonesia gave the opportunity to Avantie to totally express her ideas in kebaya 
design. In the era of digital technology, people cannot isolate themselves from the outside world. No one can stop the influence that intertwines.

Said (1993, p. 201) wrotes that:

No one today is purely one thing. Labels like Indian, or woman, or Muslim, or American are no more than starting point, which if followed into actual experience for only a moment are quickly left behind. Imperialism consolidated the mixture of cultures and identities on a global scale. But its worst and most paradoxical gift was to allow people to believe that they were only, mainly, exclusively, white, or black, or Western, or Oriental. Yet just as human beings make their own history, they also make their own cultures and ethnic identities. No one can deny the persisting continuities of long traditions, sustained habitations, national languages, and cultural geographies, but there seems no reason except fear and prejudice to keep insisting on their separation and distinctiveness, as if that was all human life was about.

\section{References}

Avantie, A. (2012). Inspirasi, karya, dan cinta [Inspiration, creation, and love]. Jakarta, Indonesia: PT Gramedia Pustaka (pp. 72-73). [In Bahasa Indonesia]

Benjamin, W. (2006). The work of art in the age of mechanical reproduction. In M.G. Durham \& D. M. Kellner (Eds), Media and Cultural Studies. Oxford: Blackwell Publshing, (pp. 18-40).

Budianta, M. (2010). Discourse of cultural identity in Indonesia during the 1997-1998 Monetary Crisis. Inter-Asia Cultural Studies, 1(1), 109-128, DOI: 10.1080/146493700361033

Davis, D. (1995). The work of art in the age of digital reproduction (An Evolving Thesis: 19911995). Leonardo, 28(5), 381-386. doi:10.2307/1576221

Heryanto, A. (1998). Ethnic Identities and erasure: Chinese Indonesian in public culture. In J. S. Kahn (ed.), Southest Asian Identities, New York: I.B. Tauris Publisher, (p. 126).

Lessig, L. (2004). The future of ideas: The fate of the commons in a connected world. New York, NY: Random House, (p. 4).

Said, E. (1993). Culture and imperialism. London, England: Chatto \& Windus, (p 201).

Screberny, A. (2006). The global and the local in international communication. In M.G. Durham \& D. M. Kellner (Eds), Media and Cultural Studies. Oxford, England: Blackwell Publshing, (pp. 604-625).

Triyanto. (2011). Eksistensi kebaya dari masa ke masa. [The kebaya existence from time to time]. Klaten, Indonesia: PT Intan Sejati. (p. 18). [In Bahasa Indonesia]

Uno, R.M. (2014). Kebayaku [My Kebaya]. Jakarta, Indonesia: PT Gramedia Pustaka Utama, (p. 28). [In Bahasa Indonesia]

Upstone, S. (2008). Spatial politics in the postcolonial novel. London, England: Ashgate. (p. 6).

Walton, D. 2008. Introducing cultural studies, learning through practice. London: SAGE Publications, (p. 101).

Yuastuti, E., \& Pamungkas, Y. (2016). Gaya busana Siti Hartinah Soeharto sebagai ibu negara tahun 19681996 [Siti Hartinah fashion style as first lady at 1968-1996]. Avatara, e-journal Pendidikan Sejarah Universitas Negeri Surabaya 4(2), 563-577. [In Bahasa Indonesia] 